\title{
Genetic variability for iron and zinc content in common bean lines and interaction with water availability
}

\author{
H.S. Pereira, M.J. Del Peloso, P.Z. Bassinello, C.M. Guimarães, \\ L.C. Melo and L.C. Faria \\ Embrapa Arroz e Feijão, Santo Antônio de Goiás, GO, Brasil \\ Corresponding author: H.S. Pereira \\ E-mail: helton.pereira@embrapa.br
}

Genet. Mol. Res. 13 (3): 6773-6785 (2014)

Received November 25, 2013

Accepted July 26, 2014

Published August 28, 2014

DOI http://dx.doi.org/10.4238/2014.August.28.21

\begin{abstract}
The common bean is an important source of iron and zinc in humans. Increases in the contents of these minerals can combat mineral deficiencies, but these contents are influenced by environmental conditions. Thus, the objectives of this study were to investigate the interaction between common bean lines and water availability on iron and zinc contents ( $\mathrm{CFe}$ and $\mathrm{CZn}$, respectively), identify superior lines with stable $\mathrm{CFe}$ and $\mathrm{CZn}$, and test for a genetic relationship between $\mathrm{CFe}$ and $\mathrm{CZn}$. Six crop trials were performed using a randomized block design with three replications. The trials were performed during the winter sowing period for three different combinations of year and site in Brazil. For each combination, 53 lines were evaluated across two parallel trials; one trial was irrigated according to the crop requirements, and the other trial operated under a water deficit. Interaction was detected between lines and environments, and between lines and water availability for $\mathrm{CFe}$ and $\mathrm{CZn}$. However, some lines exhibited high CFe and CZn in both conditions. Lines G 6492 and G 6490 exhibited high mean values, stability, and adaptability for both minerals. Other lines exhibited high CFe (Xamego) or CZn (Bambuí and Iapar 65). A
\end{abstract}


moderate genetic correlation (0.62) between $\mathrm{CFe}$ and $\mathrm{CZn}$ was detected. Water availability during the common bean cycle had an effect on $\mathrm{CFe}$ and $\mathrm{CZn}$; however, lines with high $\mathrm{CFe}$ and $\mathrm{CZn}$ in different conditions of water availability and environment were detected.

Key words: Phaseolus vulgaris L.; Drought; Nutritional quality; Genotype x environment interaction; Minerals; Biofortification

\section{INTROCUCTION}

Brazil has been the world's largest producer of the common bean (Phaseolus vulgaris L.) in recent years (Food and Agriculture Organization, 2011), with a current annual production of 2.8 million tons and an average yield of $1223 \mathrm{~kg} / \mathrm{ha}$ (Feijão, 2012). This legume represents an important source of protein for the Brazilian population, especially low-income groups. These beans are rich in protein and minerals such as iron $(\mathrm{Fe})$ and zinc $(\mathrm{Zn})$. Deficiencies in these two minerals are among the most common nutritional deficiencies in human populations worldwide and can lead to serious health problems (Welch and Graham, 1999). $\mathrm{Fe}$ is essential for the formation of hemoglobin, and Fe deficiency causes anemia. $\mathrm{Zn}$ is necessary for the hepatic mobilization of vitamin A and functions in sexual maturation, fertility, and reproduction. Zn deficiency causes growth retardation, delayed sexual maturation, loss of appetite, and glucose intolerance (Ribeiro et al., 2008).

One method for combating Fe and $\mathrm{Zn}$ deficiencies is to increase the contents of these minerals in food crops so that greater quantities of these minerals are available to the consumer. This strategy has been referred to as biofortification. Some studies have reported the existence of genetic variability with regards to Fe content $(\mathrm{CFe})$ and $\mathrm{Zn}$ content $(\mathrm{CZn})$ in beans, suggesting that lines could be selected and produced to contain higher concentrations of these minerals; furthermore, a number of lines with high $\mathrm{CFe}$ and $\mathrm{CZn}$ have already been identified (Beebe et al., 2000; Araújo et al., 2003; Ribeiro et al., 2008; Silva et al., 2012).

Although a number of lines have already been identified to contain relatively high $\mathrm{CFe}$ and $\mathrm{CZn}$, there are few reports on breeding programs that have produced such lines (Blair et al., 2009; Silva et al., 2012; Jost et al., 2013). With regard to the genetic control of these traits, most studies have reported that the inheritance of $\mathrm{CFe}$ and $\mathrm{CZn}$ is quantitative (Blair et al., 2009; Jost et al., 2013), although some studies show evidence of monogenic inheritance for $\mathrm{Zn}$ (Forster et al., 2002; Cichy et al., 2005).

Another aspect to consider is that most of the studies were conducted to identify potential breeding parents or analyze genetic control of mineral contents using a small number of trials. Because these traits are most likely quantitative, it is expected that the environment would have a substantial effect, and the genotype $\mathrm{x}$ environment interaction should be important in determining $\mathrm{CFe}$ and $\mathrm{CZn}$.

The genotype $\mathrm{x}$ environment interaction has been reported to have a notable effect on both Fe and Zn contents (Cichy et al., 2009; Tryphone and Msolla, 2010). However, other studies have detected an effect only for $\mathrm{CZn}$ or $\mathrm{CFe}$; some studies reported no evidence of genotype $\mathrm{x}$ environment interaction or that this interaction had limited significance, either for $\mathrm{CFe}$ or $\mathrm{CFe}$ and CZn (Araújo et al., 2003; Ribeiro et al., 2008; Blair et al., 2011). Thus, there is no consensus on the effect of the genotype $\mathrm{x}$ environment interaction with regard to these minerals. 
When the genotype $\mathrm{x}$ environment interaction is shown to play an important role in the expression of a trait, adaptability and stability analyses can be used to identify superior lines. This is particularly important in Brazil because common beans are sown at three different times throughout the year (i.e., dry sowing in January/February, winter sowing in May/June, and water sowing in October/November), and environmental conditions vary from one season to the next. One environmental factor with high variability is the availability of water during the crop cycle, which may or may not influence CFe and CZn. There are no reports on the effects of the genotype $\mathrm{x}$ environment interaction on $\mathrm{CFe}$ and $\mathrm{CZn}$ under different conditions of water availability.

Another interesting question is whether there is a relationship between $\mathrm{CFe}$ and $\mathrm{CZn}$, because such a relationship may facilitate the selection of lines that have high levels of both minerals. Some studies have reported a correlation between CFe and CZn (GuzmanMaldonado et al., 2003; Gelin et al., 2007; Blair et al., 2009; Cichy et al., 2009). These studies used recombinant lines derived from crosses between one parent with high $\mathrm{CFe}$ and $\mathrm{CZn}$ and another with low levels of these minerals. Other studies using lines of different genetic origins have also shown evidence of a relationship between $\mathrm{CFe}$ and $\mathrm{CZn}$ (Welch et al., 2000; Silva et al., 2012); however, additional studies found no evidence of a relationship between CFe and CZn (Ribeiro et al., 2008).

Therefore, the objectives of this study were to 1) investigate the interaction between crop lines and water supply on CFe and CZn in the common bean; 2) identify common bean lines with high $\mathrm{CFe}, \mathrm{CZn}$, and stability for these traits to guide the selection of potential parents for breeding programs; and 3) analyze the genetic relationship between the levels of the two minerals in common beans.

\section{MATERIAL AND METHODS}

\section{Field experiments}

A total of 53 lines of the common bean, including lines developed in Brazil as well as those from other countries, were evaluated. The lines in this study included the following bean types: 22 black beans, 12 beige/brown beans ('carioca'), 11 beige beans, 2 brown beans, 2 beige/red beans, 2 red beans, 1 yellow bean, and 1 white bean. The trials were conducted for three site-year combinations in the State of Goiás, Brazil; the beans were planted in the winter (May/June). A randomized block design was used consisting of three replicates in plots of two rows measuring $3 \mathrm{~m}$ in length. The site-year combinations for the trials were as follows: Santo Antônio de Goiás (2007); Porangatu (2006); and Porangatu (2007). The winter sowing period in these locations is characterized by the absence of precipitation (Heinemann et al., 2007), which was essential for controlling the amount of water in the experiments. The water supply was completely controlled by sprinkler irrigation using a movable bar with lateral displacement. In each environment, two trials were implemented in parallel, and fertilizer was applied as indicated by the guidelines for the crop. One trial was properly irrigated to maintain the soil matric potential above -0.035 MPa at $15 \mathrm{~cm}$ below the surface (Silveira and Stone, 1994), and the other trial was properly irrigated until 20 days after emergence, when the water deficit treatment was initiated (i.e., $50 \%$ reduction in irrigation). 


\section{Analyses of CFe and CZn}

Samples were obtained from each plot for the determination of CFe and CZn. Micronutrient analysis was performed three times by acid digestion of organic matter (2:1 nitric:perchloric acid mixture) according to the flame atomic absorption spectroscopy technique adapted by the Association of Official Analytical Chemists (1995). After harvest, the beans were briefly rinsed with deionized water and dried in an oven at $60^{\circ} \mathrm{C}$ for $12 \mathrm{~h}$ (until a $6 \%$ moisture level was reached). The dry beans were ground ( $\leq 200-\mathrm{mm}$ mesh) in a zirconium oxide ball mill (Retsch MM200) with polytetrafluoroethylene recipients to prevent contamination with metallic elements. Each sample was weighed one day after grinding to allow the moisture content to reach equilibrium. Predigestion of the sample was performed with the acid mixture $\left(50^{\circ} \mathrm{C}\right.$ for $\left.30 \mathrm{~min}\right)$, followed by digestion $\left(100^{\circ} \mathrm{C}\right.$ for $30 \mathrm{~min}$ and $170^{\circ} \mathrm{C}$ for $\left.3 \mathrm{~h}\right)$. The samples were cooled to room temperature and a further $2 \mathrm{~mL}$ acid mixture was added for digestion $\left(170^{\circ} \mathrm{C}\right.$ for $\left.3 \mathrm{~h}\right)$. The extract was adequately diluted, and $\mathrm{CFe}$ and $\mathrm{CZn}$ were measured using an atomic absorption spectrophotometer (AGILENT/VARIAN SpectrAA 50 B) that was previously calibrated with standard curves for Fe and $\mathrm{Zn}$. The data means are reported on a dry matter basis after correcting for the moisture content of the sample, which was obtained by the gravimetric method at $105^{\circ} \mathrm{C}$ until a constant weight was reached (Instituto Adolfo Lutz, 1995). The glassware and materials used in the analysis were cleaned using a special washing process with a decontamination step of $5 \%(\mathrm{v}: \mathrm{v})$ nitric or hydrochloric acid solution to avoid cross contamination.

\section{Statistical analyses}

Individual analyses of variance were performed on the $\mathrm{CFe}$ and $\mathrm{CZn}$ data; the effect of treatment was fixed. To evaluate experimental precision, the coefficient of variation and the selective accuracy (SA) were estimated (de Resende and Duarte, 2007) according to the following:

$$
\mathrm{SA}=\left(1-\frac{1}{F_{c}}\right)^{0.5}
$$

for $\mathrm{F}_{\mathrm{c}} \geq 1$; when $\mathrm{F}_{\mathrm{c}}<1 \mathrm{SA}=0$; where $F_{\mathrm{c}}$ is the value of the $\mathrm{F}$ statistic for the lines.

Next, a joint analysis of variance was performed with the experiments from the three site-years, with the line $\mathrm{x}$ environment interaction subdivided into line $\mathrm{x}$ water supply (with or without a water deficit) and line $\mathrm{x}$ site-year. For this analysis, the effects of lines, site-years, and water supply were all fixed. The means were compared using the Scott Knott and Tukey tests (10\% probability). The following correlations were determined according to the procedure reported by Vencovsky and Barriga (1992); Pearson's correlation was employed for CFe and CZn using the mean values for each line and environment as well as the overall means; the genetic correlation between $\mathrm{CFe}$ and $\mathrm{CZn}$ was employed using the mean values for each line and environment as well as the overall means; and Spearman's correlation between the two water supply conditions for $\mathrm{CFe}$ and $\mathrm{CZn}$ was employed using the mean value for the 53 lines for each of the three site-year combinations as well as the overall mean values for the lines. 
Stability and adaptability were analyzed according to the method proposed by Nunes et al. (2005). Initially, the mean values for the lines in the different environments were standardized by the following expression:

$$
\mathrm{z}_{\mathrm{ij}}=\frac{\left(\bar{y}_{i j}-\bar{y}_{. j}\right)}{s_{. j}}
$$

where $z_{\mathrm{ij}}$ is the value of the standardized variable corresponding to line $i$ in environment $j ; y_{i j}$ is the mean of line $i$ in environment $j ; y_{j}$ is the mean of environment $j$; and $s_{j}$ is the phenotypic standard deviation between means of the lines in environment $j$, given by the following equation:

$$
\mathbf{s}_{. \mathrm{j}}=\sqrt{\sum_{i=1}^{t} \frac{\left(\bar{y}_{i j}-\bar{y}_{. j}\right)^{2}}{t-1}}
$$

Next, a constant of 3 was added to the values obtained of $z_{i}$ to eliminate negative values. Thus, the mean of the values of $z_{i}$ for a given line was the measure of the adaptability of the line, and the coefficient of variation in $z_{i j}\left(\mathrm{CV}_{\mathrm{i}}\right)$ for each line was a measure of the stability of the line. For the statistical analyses, SAS Institute Inc. (2008), GENES (Cruz, 2010), and SISVAR (Ferreira, 1999) were used.

\section{RESULTS AND DISCUSSION}

\section{Interaction of $\mathrm{CFe}$ and $\mathrm{CZn}$ with the environment}

The experimental coefficient of variation for $\mathrm{CFe}$ and $\mathrm{CZn}$ varied from 3.3 to $9.6 \%$ and 5.6 to $11.1 \%$, respectively, indicating a high level of experimental accuracy. The level of accuracy was confirmed by the selective accuracy estimates, which were very high $(>0.9)$ for $\mathrm{CFe}$ and high or very high (0.7-0.9) for CZn across the six experimental conditions (Cargnelutti Filho and Storck, 2009). The mean CFe for the different trials ranged from 63.7 to 74.0 $\mathrm{mg} / \mathrm{kg}$, and the mean CZn ranged from 34.2 to $41.0 \mathrm{mg} / \mathrm{kg}$. The $\mathrm{CFe}$ and $\mathrm{CZn}$ means yielded values of approximately 20 and $16 \%$, respectively, indicating the occurrence of environmental variation. This variation may be explained by variation among the assessment sites, which had the following geographic characteristics: Santo Antônio de Goiás $\left(823 \mathrm{~m}\right.$ altitude, $16^{\circ} 29^{\prime} \mathrm{S}$ and $49^{\circ} 18^{\prime} \mathrm{W}$ ) and Porangatu (396 $\mathrm{m}$ altitude, $13^{\circ} 26^{\prime} \mathrm{S}$ and $49^{\circ} 09^{\prime} \mathrm{W}$ ). Additionally, these trials were performed over 2 years with two different water availability treatments (i.e., adequate irrigation and water deficit). Mean $\mathrm{CFe}$ ranged from 63.7 to $74.0 \mathrm{mg} / \mathrm{kg}$ for the water deficit condition and 66.6 to $71.1 \mathrm{mg} / \mathrm{kg}$ for the adequate irrigation condition. For CZn, the means ranged from 36.6 to $41.0 \mathrm{mg} / \mathrm{kg}$ for the water deficit condition and 34.2 to $38.8 \mathrm{mg} / \mathrm{kg}$ for the adequate irrigation condition. All of the trials showed significant differences in CFe and CZn among the crop lines.

The ratio of the largest to smallest mean square error was $<7$ for the two traits (Table 
1), indicating that the residual variances were homogeneous (Pimentel-Gomes, 2000). The joint analyses detected significant differences in CFe and CZn based on the three main sources of variation (i.e., site-year combinations, lines, and irrigation conditions), indicating that there was variability in $\mathrm{CFe}$ and $\mathrm{CZn}$ among the lines. This variability can be explained because there was significant variation in the origins of the 53 lines used in the study, which included lines developed by several Brazilian research institutions and lines introduced from other countries. Other studies have also reported differences in $\mathrm{CFe}$ and $\mathrm{CZn}$ among different lines of the common bean (Beebe et al., 2000; Araújo et al., 2003; Ribeiro et al., 2008; Silva et al., 2012; Jost et al., 2013). The identification of water supply as a significant source of variation indicated that $\mathrm{CFe}$ and $\mathrm{CZn}$ varied according to differences in irrigation, despite the small difference in the mean $\mathrm{CFe}$ value between the water deficit and adequately irrigated crops, and the similarly small difference in the mean $\mathrm{CZn}$ value among the two irrigation conditions (Table 2). The interactions between lines and site-year combinations were also significant for both minerals (Table 1), indicating that there was a differential response of the lines to site-years, which has often been reported for other traits in the common bean (Pereira et al., 2010; Perina et al., 2010); it has even been reported in the State of Goiás, Brazil, in studies conducted during the same sowing period (Pereira et al., 2011; Torga et al., 2013). Because most studies on the genetic control of CFe and CZn have reported that inheritance is quantitative (Cichy et al., 2009; Blair et al., 2009), the genotype x environment interaction is expected to have marked significance. This interaction has been reported to have a notable effect on both minerals (Cichy et al., 2009; Tryphone and Msolla, 2010).

Table 1. Summary of joint analysis of variance examining the effect of the interaction between genotype and environment on iron and zinc contents $(\mathrm{mg} / \mathrm{kg})$ from 6 experiments using the common bean, which were conducted in the municipalities of Santo Antônio de Goiás (2006) and Porangatu (2006 and 2007) during the winter sowing period under normal irrigation and water deficit conditions.

\begin{tabular}{|c|c|c|c|c|c|}
\hline \multirow[t]{2}{*}{ Source of variation } & \multirow[t]{2}{*}{ d.f. } & \multicolumn{2}{|c|}{ Iron content } & \multicolumn{2}{|c|}{ Zinc content } \\
\hline & & MS & $P$ value & MS & P value \\
\hline Bloc/environment & 12 & 59.67 & 0.0010 & 66.20 & 0.0000 \\
\hline Lines $(\mathrm{L})$ & 52 & 650.84 & 0.0000 & 214.76 & 0.0000 \\
\hline Water availability (W) & 1 & 320.55 & 0.0001 & 1601.36 & 0.0000 \\
\hline Local-year (Y) & 2 & 4441.07 & 0.0000 & 637.13 & 0.0000 \\
\hline $\mathrm{LxW}$ & 52 & 159.92 & 0.0000 & 78.77 & 0.0000 \\
\hline$L \times Y$ & 104 & 119.61 & 0.0000 & 46.63 & 0.0000 \\
\hline $\mathrm{Y} \times \mathrm{W}$ & 2 & 1036.42 & 0.0000 & 1282.57 & 0.0000 \\
\hline $\mathrm{LxW} \times \mathrm{Y}$ & 104 & 143.71 & 0.0000 & 64.89 & 0.0000 \\
\hline Error & 624 & 21.39 & - & 10.27 & - \\
\hline Total & 953 & - & - & - & - \\
\hline Mean & & 69.19 & & 37.10 & \\
\hline CV $(\%)$ & & 6.68 & & 8.64 & \\
\hline
\end{tabular}

$\mathrm{MS}=$ mean square; $\mathrm{CV}=$ coefficient of variance.

The interactions among the lines and water supply were also significant, indicating that variation in water availability had a nonlinear effect on CFe and CZn in the lines (Table 1). However, it should be noted that the interaction may be predominantly simple, (i.e., it would not alter the classification of the lines) or complex, which would lead to changes in the classification of the lines. One method that was used for verifying the importance of the complex interaction was to estimate Spearman's correlation for the CFe and CZn means of the lines for both water supply treatments. For the overall mean $\mathrm{CFe}$ of the lines, this estimate was significant and had an intermediate value $(0.57)(\mathrm{P}<1 \%)$, indicating that the interaction was predominantly com- 
Table 2. Mean values of iron and zinc contents ( $\mathrm{mg} / \mathrm{kg}$ ) of 30 common bean lines evaluated across 6 experimental conditions conducted in the municipalities of Santo Antônio de Goiás (2006) and Porangatu (2006 and 2007) during the winter sowing period under normal irrigation and water deficit conditions.

\begin{tabular}{|c|c|c|c|c|c|c|c|c|c|}
\hline \multirow[t]{2}{*}{ Line } & \multicolumn{4}{|c|}{ Iron content } & \multirow[t]{2}{*}{ Line } & \multicolumn{4}{|c|}{ Zinc content } \\
\hline & $\mathrm{WD}^{1}$ & $\mathrm{C}$ & Normal & $\mathrm{C}$ & & WD & $\mathrm{C}$ & Normal & $\mathrm{C}$ \\
\hline G 6492 & $85.4^{\mathrm{a}}$ & 1 & $78.8^{\mathrm{a}}$ & 1 & G 12778 & $47.2^{\mathrm{a}}$ & 1 & $35.9^{d}$ & 21 \\
\hline Xamego & $81.9^{\mathrm{b}}$ & 2 & $76.4^{\mathrm{a}}$ & 8 & Brasil 0001 & $47.1^{\mathrm{a}}$ & 2 & $42.4^{\mathrm{b}}$ & 4 \\
\hline Novo Jalo & $81.2^{\mathrm{b}}$ & 3 & $64.4^{\mathrm{d}}$ & 40 & G 06500 & $47.0^{\mathrm{a}}$ & 3 & $33.7^{\mathrm{e}}$ & 36 \\
\hline G 1106 & $81.0^{\mathrm{b}}$ & 4 & $72.7^{\mathrm{c}}$ & 13 & G 1356 & $46.3^{\mathrm{a}}$ & 4 & $34.4^{\mathrm{d}}$ & 30 \\
\hline Preto com. & $79.8^{\mathrm{b}}$ & 5 & $68.2^{\mathrm{c}}$ & 31 & Iapar 65 & $44.7^{\mathrm{b}}$ & 5 & $43.0^{\mathrm{b}}$ & 2 \\
\hline G 6896 & $79.2^{\mathrm{b}}$ & 6 & $72.0^{\mathrm{c}}$ & 16 & BRS Marfim & $44.6^{\mathrm{b}}$ & 6 & $32.7^{\mathrm{e}}$ & 46 \\
\hline Carioca & $78.6^{\mathrm{b}}$ & 7 & $63.8^{\mathrm{d}}$ & 44 & FT $85-79$ & $43.4^{\mathrm{b}}$ & 7 & $36.9^{d}$ & 15 \\
\hline G 2358 & $76.6^{c}$ & 8 & $74.7^{b}$ & 9 & Bambuí & $42.9^{c}$ & 8 & $40.2^{\mathrm{c}}$ & 8 \\
\hline G 6490 & $76.2^{\mathrm{c}}$ & 9 & $71.3^{\mathrm{c}}$ & 19 & G 6490 & $42.7^{c}$ & 9 & $42.6^{b}$ & 3 \\
\hline G 1356 & $76.1^{\mathrm{c}}$ & 10 & $69.3^{\mathrm{c}}$ & 26 & G 3566 & $42.4^{\mathrm{c}}$ & 10 & $36.8^{\mathrm{d}}$ & 16 \\
\hline G 3566 & $75.0^{\mathrm{c}}$ & 11 & $68.6^{c}$ & 28 & Porto Real & $42.0^{c}$ & 11 & $38.7^{c}$ & 13 \\
\hline G 18574 & $74.7^{\mathrm{c}}$ & 12 & $68.3^{\mathrm{c}}$ & 30 & G 6492 & $41.3^{\mathrm{c}}$ & 12 & $40.2^{\mathrm{c}}$ & 9 \\
\hline Piratã 1 & $74.6^{c}$ & 13 & $78.6^{\mathrm{a}}$ & 2 & G 2358 & $41.2^{\mathrm{c}}$ & 13 & $34.4^{\mathrm{d}}$ & 31 \\
\hline Sea 9 & $74.4^{\mathrm{c}}$ & 14 & $78.1^{\mathrm{a}}$ & 5 & G 2314 & $41.1^{\mathrm{c}}$ & 14 & $37.6^{\mathrm{c}}$ & 14 \\
\hline Iapar 65 & $73.7^{\mathrm{c}}$ & 15 & $73.6^{\mathrm{b}}$ & 12 & FT $84-292$ & $40.9^{c}$ & 15 & $34.7^{\mathrm{d}}$ & 29 \\
\hline BRS Marfim & $73.6^{\mathrm{c}}$ & 16 & $68.2^{\mathrm{c}}$ & 32 & G 4489 & $40.7^{\mathrm{d}}$ & 16 & $39.1^{\mathrm{c}}$ & 11 \\
\hline Brasil 0001 & $73.1^{\mathrm{c}}$ & 19 & $78.3^{\mathrm{a}}$ & 3 & G 2475 & $40.1^{\mathrm{d}}$ & 20 & $40.9^{c}$ & 7 \\
\hline Carioca MG & $68.4^{\mathrm{e}}$ & 30 & $54.2^{\mathrm{f}}$ & 52 & Pérola & $40.0^{\mathrm{d}}$ & 21 & $35.7^{\mathrm{d}}$ & 23 \\
\hline G 2475 & $68.4^{\mathrm{e}}$ & 31 & $70.8^{c}$ & 20 & Xamego & $39.9^{d}$ & 22 & $41.4^{\mathrm{b}}$ & 6 \\
\hline IPA 7 & $68.1^{\mathrm{e}}$ & 32 & $76.6^{\mathrm{a}}$ & 7 & G 278 & $37.0^{\mathrm{e}}$ & 32 & $35.2^{\mathrm{d}}$ & 26 \\
\hline BRS Valente & $67.8^{\mathrm{e}}$ & 33 & $69.7^{\circ}$ & 25 & BRSMG Talismã & $36.8^{\mathrm{e}}$ & 33 & $36.6^{\mathrm{d}}$ & 17 \\
\hline FT 84 - 292 & $67.3^{\mathrm{e}}$ & 34 & $68.1^{\mathrm{c}}$ & 33 & Piratã 1 & $36.7^{\mathrm{e}}$ & 34 & $47.0^{\mathrm{a}}$ & 1 \\
\hline Aporé & $66.6^{\mathrm{e}}$ & 35 & $65.0^{\mathrm{d}}$ & 38 & Preto com. & $35.9^{\mathrm{e}}$ & 35 & $36.4^{\mathrm{d}}$ & 19 \\
\hline Pérola & $65.9^{f}$ & 36 & $67.8^{c}$ & 34 & IAC Una & $35.0^{\mathrm{e}}$ & 41 & $30.1^{\mathrm{f}}$ & 52 \\
\hline BRSMG Talismã & $63.9^{f}$ & 43 & $72.4^{\mathrm{c}}$ & 14 & Novo Jalo & $33.6^{\mathrm{f}}$ & 46 & $30.8^{\mathrm{f}}$ & 51 \\
\hline G 278 & $59.0^{\mathrm{g}}$ & 49 & $64.6^{d}$ & 39 & BRS Grafite & $32.7^{\mathrm{f}}$ & 49 & $35.0^{\mathrm{d}}$ & 27 \\
\hline G 3217 & $57.3^{\mathrm{g}}$ & 50 & $61.7^{\mathrm{d}}$ & 46 & IPA 11 & $32.3^{\mathrm{f}}$ & 50 & $33.1^{\mathrm{e}}$ & 43 \\
\hline Iapar 31 & $56.9^{\mathrm{g}}$ & 51 & $51.2^{\mathrm{f}}$ & 53 & G 3217 & $32.0^{\mathrm{f}}$ & 51 & $31.3^{\mathrm{f}}$ & 49 \\
\hline IAC Una & $56.0^{\mathrm{g}}$ & 52 & $61.2^{\mathrm{d}}$ & 48 & IPA 7 & $31.3^{\mathrm{f}}$ & 52 & $35.7^{\mathrm{d}}$ & 24 \\
\hline G 13571 & $55.7^{\mathrm{g}}$ & 53 & $61.7^{\mathrm{d}}$ & 47 & Iapar 31 & $29.0^{\mathrm{g}}$ & 53 & $28.8^{\mathrm{f}}$ & 53 \\
\hline General mean & $69.8^{\mathrm{A}}$ & - & $68.6^{\mathrm{B}}$ & - & General mean & $38.4^{\mathrm{A}}$ & - & $35.8^{\mathrm{B}}$ & - \\
\hline
\end{tabular}

$\mathrm{WD}=$ water deficit conditions; $\mathrm{C}=$ classification. ${ }^{1}$ Means followed by the same superscript letter do not differ significantly by the Scott-Knott test (10\% probability); between lines, with the lowercase letters; between general means, with capital letters.

plex, (i.e., the water supply altered the classification of the lines). When the three site-years were analyzed separately, the results suggested low correlations of $0.29,0.33$, and 0.38 for Porangatu (2007), Porangatu (2006), and Santo Antônio de Goiás (2006), respectively. For the mean CZn, the correlation was significant and intermediate $(0.54)$, with greater variation among the siteyears [0.05, 0.44, and 0.33 for Porangatu (2007), Porangatu (2006), and Santo Antônio de Goiás (2006), respectively], indicating that the complex interaction was also important for $\mathrm{Zn}$.

For the selection of lines, we investigated whether the same lines exhibited similarly high levels of minerals when subjected to the two different conditions of water availability. Based on an analysis of the $\mathrm{CFe}$ and CZn mean values (Table 2), the following results were observed. Among the 15 lines with relatively high CFe or CZn under water deficit conditions (28\% of all lines), 7 lines (i.e., G 6492, Xamego, G 1106, G2358, Piratã 1, Sea 9, and Iapar 65) remained among the top 15 lines for $\mathrm{CFe}$ under conditions of normal water availability, and 8 lines (i.e., Brasil 0001, Iapar 65, FT 85-79, Bambuí, G 6490, Porto Real, G 6492 , and G 2314) remained among the top 15 lines for CZn. The agreement was intermediate $(50 \%)$ for both conditions of water availability, indicating the occurrence of a complex 
interaction. However, these results also demonstrates that it is possible to select superior lines under both irrigation conditions, which is of interest given that water deficit is not a factor that can be controlled.

Although the general trend observed was that described above, $\mathrm{CFe}$ and $\mathrm{CZn}$ varied widely among some of the lines depending on the availability of water (Table 2). The Novo Jalo line exhibited the 3rd highest CFe under water deficit conditions, but ranked 40th in $\mathrm{CFe}$ under adequate irrigation conditions. The IPA7 line showed the opposite response; it ranked 32nd in $\mathrm{CFe}$ with a water deficit and 7th under normal irrigation conditions. For $\mathrm{CZn}$, the BRS Marfim cultivar ranked 6th under water deficit conditions but had a CZn of only $32.7 \mathrm{mg} / \mathrm{kg}$ under normal irrigation conditions, thus ranking 46th among all the lines. The cultivar Piratã 1 with a water deficit ranked 34th but showed the highest CZn with adequate irrigation. These results show the importance of the complex interaction among water availability and lines and confirm the need for mineral content evaluations across different environmental conditions.

\section{Identification of lines with higher CFe and CZn and greater stability and adaptability}

To identify the lines that had higher $\mathrm{CFe}$ and $\mathrm{CZn}$ and, therefore, more promising for use in crossbreeding, the mean $\mathrm{CFe}$ and $\mathrm{CZn}$ values from the six trials were analyzed together, regardless of water availability conditions. For $\mathrm{CFe}$, the first four groups identified by the cluster test contained the 15 lines with the highest mineral content (Table 3). Among these lines, G $6492(82.11 \mathrm{mg} / \mathrm{kg})$ and Xamego $(79.17 \mathrm{mg} / \mathrm{kg})$ showed interesting results. The CFe of the Pérola cultivar, the most widely used common bean in Brazil, was $66.83 \mathrm{mg} / \mathrm{kg}$ (Table 4), which was approximately $23 \%$ lower than the highest mean $\mathrm{CFe}$ value. Based on nutritional information, including the daily adult requirement for iron (i.e., $14 \mathrm{mg}$ /day) (Food and Nutrition Board, 2001) and the average consumption of beans per capita in Brazil (i.e, $18 \mathrm{~kg} / \mathrm{year}$, or $50 \mathrm{~g} /$ day) (Wander, 2007), consumption of the Pérola cultivar would provide $3.3 \mathrm{mg}$ of Fe per day to an adult. This amount of Fe would represent $23.6 \%$ of the daily requirement for that mineral. Substituting the Pérola cultivar with the G 6492 line in this scenario could represent an increase in consumed Fe to $4.1 \mathrm{mg}$ (an increase of 23\%), which would account for $29.3 \%$ of the daily human requirement for Fe. Nonetheless, this analysis illustrates the importance of developing bean cultivars with higher $\mathrm{CFe}$, especially for consumption by people with low purchasing power.

For $\mathrm{CZn}$, the first 3 groups identified by the cluster test grouped the 15 lines with the highest concentrations (Table 3). Three lines showed high levels of Zn: Brasil 0001, Iapar 65, and G 6490. The Pérola cultivar had a CZn value $(37.83 \mathrm{mg} / \mathrm{kg})$ that was $18 \%$ lower than the $\mathrm{CZn}$ value of the Brasil 0001 line. With a daily human $\mathrm{Zn}$ requirement of $7 \mathrm{mg} / \mathrm{day}$, consuming the Pérola bean would provide approximately $1.89 \mathrm{mg}$ of $\mathrm{Zn}$ per day, representing $27 \%$ of the daily human requirement for this nutrient. Consuming the Brasil 0001 bean would result in a daily consumption of $2.24 \mathrm{mg}$ of $\mathrm{Zn}$ (a relative increase of $18.4 \%$ ), thus providing $32 \%$ of the daily human requirement. Based on the range of CFe $(54.06$ to $82.11 \mathrm{mg} / \mathrm{kg}$ ) and CZn ( 28.89 to $44.78 \mathrm{mg} / \mathrm{kg}$ ) among the breeding lines, there is great variability in mineral content among genotypes, and it is possible to select lines with relatively high levels of these minerals (Tables 3 and 4). 
Table 3. Mean values of iron and zinc contents $(\mathrm{mg} / \mathrm{kg})$ and parameters of adaptability and stability for the 27 common bean lines with the greatest iron content, evaluated across 6 experimental conditions conducted in the municipalities of Santo Antônio de Goiás (2006) and Porangatu (2006 and 2007) during the winter sowing period under conditions of normal irrigation and water deficit.

\begin{tabular}{|c|c|c|c|c|c|c|c|}
\hline \multirow[t]{2}{*}{ Line } & \multirow[t]{2}{*}{ Grain color } & \multicolumn{3}{|c|}{ Iron content } & \multicolumn{3}{|c|}{ Zinc content } \\
\hline & & Mean $^{1}$ & $z_{i j}$ & $\mathrm{CV}_{\mathrm{i}}$ & Mean & $z_{i j}$ & $\mathrm{CV}_{\mathrm{i}}$ \\
\hline G 6492 & Black & $82.11^{\mathrm{a}}$ & 4.49 & 20.56 & $40.78^{b}$ & 3.79 & 20.61 \\
\hline Xamego & Black & $79.17^{b}$ & 4.10 & 18.41 & $40.67^{b}$ & 3.76 & 29.45 \\
\hline G 1106 & White & $76.83^{\mathrm{c}}$ & 3.91 & 17.89 & $36.94^{\mathrm{e}}$ & 2.83 & 27.16 \\
\hline Piratã 1 & Cream & $76.56^{c}$ & 3.83 & 13.60 & $41.83^{b}$ & 4.10 & 36.14 \\
\hline Sea 9 & Cream & $76.28^{c}$ & 3.82 & 10.29 & $41.11^{\mathrm{b}}$ & 3.91 & 25.95 \\
\hline Brasil 0001 & Brown & $75.72^{\mathrm{c}}$ & 3.84 & 34.33 & $44.78^{\mathrm{a}}$ & 4.46 & 16.48 \\
\hline G 6896 & Cream & $75.61^{\mathrm{c}}$ & 3.75 & 22.36 & $34.11^{\mathrm{f}}$ & 2.32 & 27.74 \\
\hline G 2358 & Cream & $75.61^{c}$ & 3.78 & 10.36 & $37.83^{\mathrm{d}}$ & 2.99 & 24.44 \\
\hline Sea 7 & Brown & $75.39^{c}$ & 3.73 & 17.69 & $37.61^{d}$ & 3.22 & 25.55 \\
\hline G 14378 & Cream & $75.28^{c}$ & 3.81 & 22.97 & $35.11^{\mathrm{e}}$ & 2.59 & 21.79 \\
\hline Preto comum & Black & $74.00^{\mathrm{d}}$ & 3.52 & 21.66 & $36.17^{\mathrm{e}}$ & 2.88 & 31.23 \\
\hline G 6490 & Black & $73.78^{d}$ & 3.49 & 14.78 & $42.61^{\mathrm{a}}$ & 4.12 & 17.73 \\
\hline Iapar 65 & Black & $73.61^{d}$ & 3.47 & 16.82 & $43.83^{\mathrm{a}}$ & 4.31 & 20.47 \\
\hline G 12778 & Cream & $73.50^{\mathrm{d}}$ & 3.49 & 18.06 & $41.56^{\mathrm{b}}$ & 3.68 & 27.68 \\
\hline G 2314 & Black & $73.39^{d}$ & 3.52 & 29.69 & $39.33^{\mathrm{c}}$ & 3.35 & 23.77 \\
\hline Novo Jalo & Yelow & $72.83^{\mathrm{e}}$ & 3.50 & 36.51 & $32.17^{\mathrm{f}}$ & 2.02 & 26.33 \\
\hline G 1356 & Red & $72.72^{\mathrm{e}}$ & 3.38 & 13.25 & $40.39^{b}$ & 3.48 & 28.46 \\
\hline IPA 7 & Cream & $72.33^{\mathrm{e}}$ & 3.36 & 21.97 & $33.50^{\mathrm{g}}$ & 2.34 & 44.33 \\
\hline G 3566 & Black & $71.78^{\mathrm{e}}$ & 3.34 & 21.22 & $39.61^{\mathrm{c}}$ & 3.49 & 17.17 \\
\hline G 2227 & Black & $71.67^{\mathrm{e}}$ & 3.35 & 26.08 & $34.89^{\mathrm{e}}$ & 2.56 & 15.38 \\
\hline G 18574 & Black & $71.50^{\mathrm{e}}$ & 3.23 & 31.37 & $39.56^{\mathrm{c}}$ & 3.49 & 30.37 \\
\hline Porto Real & Cream/brown & $71.28^{\mathrm{e}}$ & 3.29 & 35.84 & $40.33^{b}$ & 3.66 & 20.70 \\
\hline Carioca & Cream/brown & $71.17^{\mathrm{e}}$ & 3.21 & 28.25 & $35.67^{\mathrm{e}}$ & 2.72 & 34.52 \\
\hline G 4489 & Black & $71.06^{\mathrm{e}}$ & 3.25 & 13.31 & $39.89^{c}$ & 3.56 & 9.69 \\
\hline BRS Marfim & Cream & $70.89^{\mathrm{e}}$ & 3.19 & 26.33 & $38.61^{\mathrm{d}}$ & 3.17 & 38.35 \\
\hline EMP 86 & Cream & $70.67^{\mathrm{e}}$ & 3.14 & 14.29 & $34.72^{\mathrm{e}}$ & 2.73 & 48.47 \\
\hline Rico V. MG & Black & $70.39^{\mathrm{e}}$ & 3.13 & 11.75 & $36.56^{\mathrm{e}}$ & 2.94 & 14.04 \\
\hline General mean & & 69.19 & - & 11.13 & 37.10 & $\begin{array}{l}2.94 \\
-\end{array}$ & $\begin{array}{l}14.04 \\
-\end{array}$ \\
\hline
\end{tabular}

The values in bold indicate the 15 best lines for each parameter evaluated; $z_{i j}=$ value of the standardized variable (adaptability parameter); $\mathrm{CV}_{\mathrm{i}}=$ coefficient of variation of the standardized variable for each line (stability parameter). ${ }^{1}$ Means followed by the same superscript letter are not significantly different by the Scott-Knott test (10\% probability).

In this study, it was found that the line $\mathrm{x}$ environment (site-year and water supply) interaction was important (Table 1) and that lines do not perform similarly across different environments with regard to mineral content. Therefore, it is important to identify lines that contain high average values of $\mathrm{CFe}$ and $\mathrm{CZn}$ and are stable and well adapted. The method established by Nunes et al. (2005) provides information on adaptability using the $z_{i}$ statistic and evaluates stability using the $\mathrm{CV}_{\mathrm{i}}$. Based on the values of $\mathrm{z}_{\mathrm{i}}$ for $\mathrm{CFe}$, the most well adapted lines were G 6492 and Xamego (Table 3). In general, for the 15 lines with the highest average $\mathrm{CFe}$ values, 14 lines also showed high values of $z_{i}$, indicating that the relationship between $\mathrm{CFe}$ and $\mathrm{z}_{\mathrm{i}}$ was strong. The estimates of $\mathrm{CV}_{\mathrm{i}}$ varied greatly (10.29-46.23\%), indicating a high degree of variation in the stability of the lines (Tables 3 and 4). The lines Sea 9 and Sea 7 were the most stable. Among the 15 lines with the highest CFe values, 9 were among the most stable lines. In addition, G 6492, which had the highest average CFe value, ranked number 16 with respect to stability.

Considering the mean CFe value, adaptability, and stability, 9 lines were identified as having potential for use in breeding programs seeking to increase $\mathrm{CFe}$ in common beans, including G 6492, Xamego, G 1106, Piratã 1, Sea 9, G 2358, Sea 7, G 6490, and G 12778 (Table 
3). The black bean Xamego is a recommended cultivar in some Brazilian states and is a line that has other favorable agronomic traits.

\begin{tabular}{|c|c|c|c|c|c|c|c|}
\hline \multirow[t]{2}{*}{ Line } & \multirow[t]{2}{*}{ Grain color } & \multicolumn{3}{|c|}{ Iron content } & \multicolumn{3}{|c|}{ Zinc content } \\
\hline & & Mean $^{1}$ & $z_{i j}$ & $\mathrm{CV}_{\mathrm{i}}$ & Mean & $z_{i j}$ & $\mathrm{CV}_{\mathrm{i}}$ \\
\hline G 06500 & Cream/red & $70.17^{\circ}$ & 3.11 & 26.42 & $40.33^{b}$ & 3.46 & 32.91 \\
\hline G 2475 & Cream/red & $69.61^{\mathrm{f}}$ & 2.99 & 21.32 & $40.50^{b}$ & 3.66 & 15.53 \\
\hline BRS Valente & Black & $68.72^{\mathrm{f}}$ & 2.98 & 11.89 & $36.11^{\mathrm{e}}$ & 2.84 & 18.49 \\
\hline Vermelho 2157 & Red & $68.72^{\mathrm{f}}$ & 2.95 & 23.02 & $36.50^{\mathrm{e}}$ & 2.94 & 34.36 \\
\hline G 3474 & Black & $68.56^{\mathrm{f}}$ & 2.88 & 25.93 & $34.50^{\mathrm{e}}$ & 2.57 & 25.83 \\
\hline BRS Grafite & Black & $68.33^{\mathrm{f}}$ & 2.84 & 39.80 & $33.83^{\mathrm{f}}$ & 2.49 & 49.20 \\
\hline BRSMG Talismã & Cream/brown & $68.17^{\mathrm{f}}$ & 2.94 & 27.53 & $36.67^{\mathrm{e}}$ & 3.02 & 31.23 \\
\hline FT 84 - 292 & Cream/brown & $67.72^{\mathrm{f}}$ & 2.85 & 28.18 & $37.78^{d}$ & 3.07 & 19.09 \\
\hline Pérola & Cream/brown & $66.83^{\mathrm{g}}$ & 2.74 & 32.82 & $37.83^{\mathrm{d}}$ & 3.17 & 16.09 \\
\hline IPA 11 & Cream/brown & $66.61^{\mathrm{g}}$ & 2.72 & 24.89 & $32.72^{\mathrm{f}}$ & 2.23 & 24.40 \\
\hline FT $85-79$ & Cream/brown & $66.06^{\mathrm{g}}$ & 2.55 & 38.43 & $40.17^{b}$ & 3.44 & 21.01 \\
\hline Bat 304 & Black & $65.89^{\mathrm{g}}$ & 2.60 & 17.68 & $37.83^{\mathrm{d}}$ & 2.97 & 33.09 \\
\hline Aporé & Cream/brown & $65.78^{\mathrm{g}}$ & 2.56 & 32.85 & $37.33^{\mathrm{d}}$ & 3.14 & 17.41 \\
\hline Coco Blanchi & Black & $65.44^{\mathrm{g}}$ & 2.62 & 20.75 & $33.50^{\mathrm{f}}$ & 2.25 & 20.37 \\
\hline G 18649 & Black & $64.67^{\mathrm{g}}$ & 2.55 & 27.11 & $34.94^{\circ}$ & 2.65 & 24.90 \\
\hline G 2359 & Black & $63.83^{\mathrm{h}}$ & 2.39 & 30.97 & $35.00^{\circ}$ & 2.48 & 28.81 \\
\hline G 4280 & Black & $63.06^{\mathrm{h}}$ & 2.27 & 28.54 & $34.67^{\circ}$ & 2.61 & 26.60 \\
\hline Bambuí & Cream & $62.50^{\mathrm{h}}$ & 2.18 & 46.11 & $41.56^{b}$ & 3.89 & 10.85 \\
\hline G 278 & Black & $61.78^{\mathrm{i}}$ & 2.14 & 28.86 & $36.11^{\mathrm{c}}$ & 2.73 & 26.43 \\
\hline Carioca MG & Cream/brown & $61.33^{\mathrm{i}}$ & 2.07 & 43.75 & $32.72^{\mathrm{f}}$ & 2.16 & 28.06 \\
\hline G 3217 & Black & $59.50^{\mathrm{i}}$ & 1.92 & 32.89 & $31.67^{\mathrm{f}}$ & 1.95 & 18.55 \\
\hline G 4825 & Cream/brown & $59.33^{\mathrm{i}}$ & 1.81 & 28.39 & $33.33^{\mathrm{f}}$ & 2.23 & 33.60 \\
\hline G 13571 & Cream & $58.67^{\mathrm{j}}$ & 1.75 & 36.46 & $36.11^{\mathrm{e}}$ & 2.75 & 13.95 \\
\hline IAC Una & Black & $58.61^{\mathrm{j}}$ & 1.74 & 44.82 & $32.56^{\mathrm{f}}$ & 2.10 & 36.36 \\
\hline A 78 & Cream/brown & $58.11^{\mathrm{j}}$ & 1.73 & 41.10 & $33.11^{\mathrm{f}}$ & 2.37 & 35.04 \\
\hline Iapar 31 & Cream/brown & $54.06^{\mathrm{k}}$ & 1.20 & 46.23 & $28.89^{\mathrm{g}}$ & 1.36 & 49.22 \\
\hline General mean & & 69.19 & - & - & 37.10 & - & - \\
\hline
\end{tabular}

The values in bold indicate the 15 lines with the highest values for each parameter evaluated. ${ }^{1}$ Means followed by the same superscript letter are not significantly different by the Scott-Knott test (10\% probability).

For CZn, the most well adapted lines were Brasil 0001 and Iapar 65 (Table 3). Among the 15 lines with the highest mean CZn values, 13 also had high values of $z_{i}$, confirming a strong relationship between the mean $\mathrm{CZn}$ and $\mathrm{z}_{\mathrm{i}}$. Similar to the results for $\mathrm{CFe}$, the estimates of $\mathrm{CV}_{\mathrm{i}}$ ranged from 9.69 to $49.22 \%$, showing a high degree of variation in the stability of the lines (Tables 3 and 4). The cultivars BRS Marfim and Bambuí were the most stable. Of the 15 lines with the highest $\mathrm{CZn}$ values, 5 lines also were among the most 15 stable. In addition, the lines Iapar 65, Brasil 0001, and Porto Real, which ranked 2nd, 1st, and 12th, respectively, with regard to $\mathrm{CZn}$; they ranked 16 th, 17 th, and 18th with regard to stability. The $\mathrm{CV}_{\mathrm{i}}$ estimates for these lines were very similar to the estimate for the 15th most stable line $\left(\mathrm{CV}_{\mathrm{i}}=20.37 \%\right)$. Based on the results for the mean CZn values, CZn adaptability, and CZn stability, 8 lines may have potential uses in breeding programs seeking to increase $\mathrm{CZn}$ in beans, including Brasil 0001, Iapar 65, G 6490, G 6492, Porto Real, G 4489, G 2475, and Bambuí (Tables 3 and 4). The cultivars Iapar 65 (black bean) and Bambuí (beige bean) are also noteworthy because they exhibited other favorable agronomic traits.

A comparison of the lines with the highest potential for use in breeding programs to 
increase $\mathrm{CFe}$ and $\mathrm{CZn}$ showed that only a few lines yielded increased levels of both minerals. To simultaneously improve CFe and CZn, the best lines were G 6492 and G 6490, which are black beans (Tables 3 and 4).

\section{Relationship between CFe and CZn}

The phenotypic correlation $\left(r_{f}\right)$ obtained using the overall averages of $\mathrm{CFe}$ and $\mathrm{CZn}$ for each line was significant $(0.58)$, indicating that there was an intermediate association $(0.41$ $<\mathrm{r}_{\mathrm{f}}<0.70$ ) between the levels of the two minerals (Table 5). This result was confirmed by individual estimates for the six experiments, which varied from 0.11 to 0.70 . The individual estimates were significant in 5 of the 6 cases and were consistent with the correlation observed among the mean values. The extent of the correlation varied widely among the different experiments and ranged from no association to intermediate association, indicating the influence of environment and other associations on these characteristics. The results were similar to those found in other studies (Guzman-Maldonado et al., 2003; Gelin et al., 2007; Cichy et al., 2009; Blair et al., 2009, 2011) that examined recombinant lines obtained from crosses between one parent with high $\mathrm{CFe}$ and $\mathrm{CZn}$ and another with low levels of these minerals. In contrast, some studies using lines with different genetic backgrounds showed that this relationship does not exist (Ribeiro et al., 2008), while others reported a significant relationship (Welch et al., 2000; Silva et al., 2012) between the levels of the two minerals. A total of 18 correlation estimates from previous studies ranged from -0.08 to 0.75 , with an average of 0.46 .

Table 5. Phenotypic $\left(r_{\mathrm{f}}\right)$, genetic $\left(\mathrm{r}_{\mathrm{g}}\right)$ and environmental $\left(\mathrm{r}_{\mathrm{a}}\right)$ correlations between the iron content and zinc content, based on the averages of 53 lines evaluated across 6 experimental conditions.

\begin{tabular}{llcc}
\hline Environment & $\mathrm{r}_{\mathrm{f}}$ & $\mathrm{r}_{\mathrm{g}}$ & $\mathrm{r}_{\mathrm{a}}$ \\
\hline Porangatu 2007 WD & $0.48^{* *}$ & $0.51^{++}$ & $0.35^{++}$ \\
Porangatu 2007 N $\mathrm{N}^{2}$ & 0.11 & $0.11^{++}$ & $0.06^{++}$ \\
Santo Antônio de Goiás 2006 WD & 0.22 & $0.15^{++}$ & $0.56^{++}$ \\
Santo Antônio de Goiás 2006 N & $0.48^{* *}$ & $0.46^{+}$ & $0.75^{++}$ \\
Porangatu 2006 WD & $0.28^{*}$ & $0.33^{+}$ & $-0.08^{++}$ \\
Porangatu 2006 N & $0.70^{* *}$ & $0.72^{+}$ & $0.61^{++}$ \\
General & $0.58^{*}$ & $0.62^{++}$ & $0.26^{++}$ \\
\hline
\end{tabular}

${ }^{1} \mathrm{WD}=$ experiment with water deficit; ${ }^{2} \mathrm{~N}=$ experiment with normal irrigation; ${ }^{*}$ significant at $\mathrm{P}<1 \%(t$-test $)$; and *significant at $\mathrm{P}<5 \%$ ( $t$-test); ${ }^{++}$significant according to the resampling test via bootstrapping (Cruz, 2010).

The phenotypic correlation was the measure most frequently used in the studies cited above, but this measure has both genetic and environmental components. However, it is important to estimate the genetic correlation between traits because this correlation reflects only the genetic association (i.e., whether the genes controlling the 2 traits are linked and/or pleiotropic) (Vencovsky and Barriga, 1992). In this study, the genetic correlation estimates were similar to the phenotypic correlations. Based on the overall mean of the lines (0.62), the genetic correlations were intermediate and ranged from 0.11 to 0.72 among the experiments (Table 5). Silva et al. (2012) also found an intermediate genetic correlation between $\mathrm{Fe}$ and $\mathrm{Zn}$ (0.54). Thus, the genetic correlation estimates confirmed that there was an intermediate relationship between the levels of both minerals, and at least some of the genes controlling these traits are linked and/or pleiotropic. 


\section{CONCLUSION}

The water availability during the common bean cycle affects CFe and CZn contents in the grains of different lines. However, it is possible to identify lines with high $\mathrm{CFe}$ and $\mathrm{CZn}$ contents, simultaneously, for use in different water availability and environmental conditions.

There is an intermediate genetic correlation between $\mathrm{CFe}$ and $\mathrm{CZn}$.

The G 6492 and G 6490 lines, which are black beans, have potential for use as parents in breeding programs seeking to produce lines with both high CFe and CZn contents. Xamego (black bean), Iapar 65 (black bean), and Bambuí (beige bean) lines not only exhibited desirable agronomic traits but also showed high mean values, adaptability, and stability for $\mathrm{CFe}$ (Xamego) and CZn (Iapar 65 and Bambuí).

\section{ACKNOWLEDGMENTS}

The authors would like to thank Emater Goiás, Embrapa Arroz e Feijão, and the Harvest Plus program for supporting and funding this study. They also wish to thank the Conselho Nacional de Desenvolvimento Científico e Tecnológico (CNPq) for the Productivity Scholarship in Technological Development and Innovative Extension, which was granted to the first and fifth authors.

\section{REFERENCES}

Araújo R, Miglioranza E, Montalvan R, Destro D, et al. (2003). Genotype x environment interaction effects on the iron content of common bean grains. Crop Breed. Appl. Biotechnol. 3: 269-274.

Association of Official Analytical Chemists (1995). The Official Methods of Analysis. AOAC International, Gaithersburg. Beebe S, Gonzalez AV and Rengifo J (2000). Research on trace minerals in the common bean. Food Nutr. Bull. 21: 387-391.

Blair MW, Astudillo C, Grusak M, Graham R, et al. (2009). Inheritance of seed iron and zinc content in common bean (Phaseolus vulgaris L.). Mol. Breed. 23: 197-207.

Blair MW, Astudillo C, Rengifo J, Beebe SE, et al. (2011). QTL analyses for seed iron and zinc concentrations in an intragene pool population of Andean common beans (Phaseolus vulgaris L.). Theor. Appl. Genet. 122: 511-521.

Cargnelutti Filho A and Storck L (2009). Medidas do grau de precisão experimental em ensaios de competição de cultivares de milho. Pesq. Agropec. Bras. 44: 111-117.

Cichy KA, Forster S, Grafton KF and Hosweld GL (2005). Inheritance of seed zinc accumulation in navy bean. Crop Sci. 45: 864-870.

Cichy KA, Caldas GV, Snapp SS and Blair MW (2009). QTL analysis of seed iron, zinc, and phosphorus levels in an Andean bean population. Crop Sci. 49: 1742-1750.

Cruz CD (2010). Programa Genes: Software para Genética e Estatística. Available at [http://www.ufv.br/dbg/genes/genes. htm]. Accessed July 8, 2010.

de Resende MDV and Duarte JB (2007). Precisão e controle de qualidade em experimentos de avaliação de cultivares. Pesq. Agropec. Trop. 37: 182-194.

Feijão (2012). Dados de Produção de Feijão (Phaseolus vulgaris L.) e Caupi (Vigna unguiculata (L.) Walp) no Brasil - 1985 to 2011. Available at [http://www.cnpaf.embrapa.br/socioeconomia/index.htm]. Accessed April 10, 2012.

Ferreira DF (1999). Sistema para Análise de Variância para Dados Balanceados (SISVAR). Universidade Federal de Lavras, Lavras.

Food and Agriculture Organization (2011). Faostat. Available at [http://faostat.fao.org/site/567/DesktopDefalt. aspx?PageID=567]. Accessed May 10, 2011.

Food and Nutrition Board (2001). Dietary Reference Intakes. The National Academic Press, Washington D.C.

Forster SM, Moraghan JT and Grafton KF (2002). Inheritance of seed zinc accumulation in navy bean. Ann. Rep. Bean Improv. Coop. 45: 30-31.

Gelin JR, Forster S, Grafton KF, McClean PE, et al. (2007). Analysis of seed zinc and other minerals in a recombinant 
inbred population of navy bean (Phaseolus vulgaris L.). Crop Sci. 47: 1361-1366.

Guzman-Maldonado SH, Martinez O, Acosta-Gallegos JA, Guevara-Lara F, et al. (2003). Putative quantitative trait loci for physical and chemical components of common bean. Crop Sci. 43: 1029-1035.

Heinemann AB, Silva SC, Lopes Junior S, Amorin AO, et al (2007). Características Climáticas dos Municípios de Santo Antônio de Goiás (GO), Porangatu (GO), Sete Lagoas (MG), Janaúba (MG), Teresina (PI), Paranaíba (PI) (Documentos, 214). Embrapa Arroz e Feijão, Brasil.

Instituto Adolfo Lutz (2005). Métodos Físico-Químicos para Análise de Alimentos (Série A. Normas e Manuais Técnicos). Ministério da Saúde, Brasília.

Jost E, Ribeiro ND, Maziero SM, Possobom MT, et al. (2013). Comparison among direct, indirect and index selections on agronomic traits and nutritional quality traits in common bean. J. Sci. Food Agric. 93: 1097-1104.

Nunes JAR, Ramalho MAP and Abreu AFB (2005). Graphical method in studies of adaptability and stability of cultivars. Ann. Rep. Bean Improv. Coop. 48: 182-183.

Pereira HS, Melo LC, Faria LC, Del Peloso MJ, et al. (2010). Indicação de cultivares de feijoeiro-comum baseada na avaliação conjunta de diferentes épocas de semeadura. Pesq. Agropec. Bras. 45: 571-578.

Pereira HS, Melo LC, Faria LC, Del Peloso MJ, et al. (2011). Complex interaction between genotypes and growing seasons of the carioca common bean in Goiás/Distrito Federal. Crop Breed. Appl. Biotechnol. 11: 207-215.

Perina EF, Carvalho CRL, Chiorato AF, Gonçalves JGR, et al. (2010). Avaliação de estabilidade e adaptabilidade de genótipos de feijoeiro (Phaseolus vulgaris L.) baseada na análise multivariada da performance genotípica. Cienc. Agrotecnol. 34: 398-406.

Pimentel-Gomes FP (2000). Curso de Estatística Experimental. Editora Nobel, São Paulo.

Ribeiro ND, Jost E, Cerutti T, Maziero SM, et al. (2008). Micromineral composition of common bean cultivars and its application in crop breeding. Bragantia 67: 267-273.

SAS Institute Inc. (2008). SAS/STAT ${ }^{\circledR} 9.2$ Users's Guide. Version 9.2. SAS Institute Inc., Cary.

Silva CA, Abreu AFB, Ramalho MAP and Maia LGS (2012). Chemical composition as related to seed color of common bean. Crop Breed. Appl. Biotechnol. 12: 132-137.

Silveira PM da and Stone LF (1994). Manejo da Irrigação do Feijoeiro: Uso do Tensiômetro e Avaliação do Desempenho do Pivô Central. Documentos 27. Embrapa Arroz e Feijão, Santo Antônio de Goiás.

Torga PP, Melo PGS, Pereira HS, Faria LC, et al. (2013). Interaction of common beans cultivars of the black group with years, locations and sowing seasons. Euphytica 189: 239-248.

Tryphone GM and Msolla N (2010). Diversity of common bean (Phaseolus vulgaris L.) genotypes in iron and zinc contents under greenhouse conditions. Afr. J. Agric. Res. 5: 738-747.

Vencovsky R and Barriga P (1992). Genética Biométrica no Fitomelhoramento. Sociedade Brasileira de Genética, Ribeirão Preto.

Wander AE (2007). Produção e consumo de feijão no Brasil, 1975-2005. Inform. Econ. 37: 7-21.

Welch RM and Graham RD (1999). A new paradigm for world agriculture: productive: meeting human needs - productive, sustainable, nutritious. Field Crops Res. 60: 1-10.

Welch RM, House WA, Beebe S and Cheng Z (2000). Genetic selection for enhanced bioavailable levels of iron in bean (Phaseolus vulgaris L.) seeds. J. Agric. Food Chem. 48: 3576-3580. 